\title{
A Study of the Social Ecological Wisdom in H.W. Longfellow's Poetry
}

\author{
Jingcheng $\mathrm{Xu}$ \\ The School of Foreign Languages, Being Forestry University, Haidian District, Beijing 100083, China \\ Email:xjc396@126.com \\ Meifang Nan Gong \\ The School of Foreign Languages, Being Forestry University, Haidian District, Beijing 100083, China \\ Email: mf.nangong@gmail.com
}

\begin{abstract}
Under eco-criticism springing up as a literary, cultural and social criticism, which aims at exploring the relationships between literature, culture, society and natural environment to find out the ecological wisdom in literary works so as to awaken the ecological consciousness of the contemporaries, the present article mainly focuses on the great American poet and intellectual thinker, Henry Wadsworth Longfellow's poems on slavery to explore his social ecological wisdom. By reading Longfellow in the light of such eco-ethical ideas as everyman being equal: anti-slavery and the harmonious development between nature and human society: anti-anthropocentrism, it is not difficult to discover the legacy glittering with social ecological wisdom in Longfellow's poetry. Such wisdom is highly connected with Longfellow's "environmental niche". Nowadays, with the increasing deterioration and decaying of the environment, and the smoldering social discrimination, the social ecological wisdom implied in Longfellow's poetry is of tremendous significance.
\end{abstract}

Index Terms - eco-criticism, Henry Wadsworth Longfellow, social ecological wisdom, "Environmental Niche"

\section{INTRODUCTION}

The $20^{\text {th }}$ century has seen a great change in literary criticism due to the rapid development of the world economy, and the gradual change of world pattern and intellectual pattern. Especially in the 1960s and 1970s, the previous dominant formalist literary criticism surrenders itself to cultural literary criticism. Accordingly, the focus and interest of literary study has since swerved from the inner rhetoric literary study to the outer cultural and social contexts related to literature. Thus, cultural study as a promising and flourish trend of thought has joined itself in the repertoire of the social cultural criticism in modern times, where has observed the booming social studies, such as Marxism, Feminism, and post-colonialism.

Eco-criticism has sprung up as a literary, cultural and social study by virtue of the fact that since the 1960s, the Earth, our Mother Nature, has seen devastating changes, and the ecosystem in a vicious circle has been suffering myriads of ecological disasters, natural or human, manufacturing pollution, global warming, expanding population, acid rain, deforestation, desertification, irregular earthquakes and eruption of volcanoes, ozone layer depletion, and melting of polar glaciers, under which circumstance the human beings' dwelling on earth and all creatures at large thus have been in danger and under hazards as well. As a result of the ecological crisis, human beings have come to realize the importance of Mother Nature, and drawn attention to and take measures to put the earth under protection and care, and literary critics have since attempted to dig out the ecological wisdom in literature.

\section{A. A Theoretical Introduction of Eco-criticism}

Eco-criticism, as one of the cultural literary criticisms, originated in the USA in the one article named Literature and Ecology: An Experiment in Ecocriticism created by American scholar William Rueckert in 1978. He advocated applying the concept of ecology into literary research. ${ }^{[1] \mathrm{XIX}}$ By definition, eco-criticism, projecting a vivid view of interdisciplinary study by its academic term, is a literary, cultural, social and artistic study under the circumstance of ecology. The application of ecology to the literary studies is of multiple significance. It is eco-poetics, by attempting to explore literary ecology or applying the concept of ecology to the literary readings, teaching, and writing. But actually, 16 years before him, Rachel Carson, an eco-litterateur, the forerunner of eco-criticism as well as a biologist studying fish and wild creatures published her work Silent Spring which was considered as "the beginning of modern environmentalism" [2225, which contains lots of knowledge of ecology, biology, and environmental science.

Entering the 1990s and $20^{\text {th }}$ century, the development of eco-criticism and ecological literature has met its bloom. ${ }^{[3] 7}$

\footnotetext{
${ }^{[1]}$ Glotfelty, Cheryll \& Haroltd Fromm (eds.). (1996).The Ecocriticism Reader: Landmarks in Literary Ecology. Athens \& London: The University of Georgia Press.

${ }^{[2]}$ Maolin Chen.(2009). Poetic Dwelling: An Ecocritical Study of Henry David Thoreau. Zhejiang: Zhejiang University Press.

${ }^{[3]}$ Renzhe Lan.(2003). Romanticism, Nature and Ecocriticism. Journal of Sichuan International Studies University,5, 3-8.
} 
It almost has touched every field and aroused environmental awareness and concern. The ecological issues are related not only to environment, but also to politics, economy, society, and even ethics. The application of ecology, a concept in the realm of natural science, to literary criticism is the realization of the marriage of literature and natural science. Under this marriage of science and humanity comes out a new mode of literary criticism in ecology, which is one of the important features in eco-criticism. In the technology-governed age, eco-criticism proceeds from the concerns of nature, and the ecosystem, and stretches the literary criticism to the range of nature and the ecosystem, which inevitably requires the interactive communication between literature and ecology in natural science and voluntarily arouses an interdisciplinary conversation. In this case, eco-criticism can reach its apogee. Several theories combining and integrating disciplines of the humanities and natural sciences are the important sources for eco-criticism. Edward O. Wilson offers the explanation of all the social behaviors based on the biological aspects of his Theory of Sociobiology. According to the Gaea Theory of another biologist, James Lovelock, the biosphere of the Earth, actively adjusts the environment, but not passively adapts itself to the environment. Therefore, the Earth has its own physiological course like an individual creature. ${ }^{[4] 147}$

It is far from enough to dissolve the ecological crisis only based on natural science. It should also be participated in and guided by humanities. The mitigation or even phasing out of the ecological crisis requires unleashing the bondage of the narrow anthropocentrism and the deconstruction of traditional disciplines based on mechanism, dualism, and reductionism. Apart from the realization of transcendence between humanity and natural science, eco-criticism should also fulfill the transcendence among humanistic disciplines. The increasingly deteriorative environment boosts the increasing awareness of the protection of the ecosystem, as the concept of ecology has already infiltrated every field of humanities, such as literature, arts, culture, politics, economy, philosophy, ethics etc. Thus, the decaying of the ecosystem has become a common issue that the humanities must confront and deal with.

Literature, one discipline of social humanities and mirroring the relationship among nature, culture and human civilization in the perspective of literary criticism, also shoulders the burdens and responsibilities to tackle the ecological crisis, although the practice seems impractical, and yet it will definitely arouse the people's awareness of protecting the earth, our Mother Nature and casting off the narrow anthropocentrism to achieve a harmonious society.

According to Chen Maolin (2009,p.1), and Lu Shuyuan (2000,p.146), leading scholars in the field of ecological research in literature and art in China, they divide the eco-critic study into the three realms: natural ecology, social ecology, and spiritual ecology. The natural ecology mainly deals with the relationship within nature and between nature and man. The social ecology concentrates on the relationship within society, and between nature and society, which is in the present article called as eco-socialism to some extent. The spiritual ecology mainly focuses on the relationship within human minds among nature, society and spirit.

The present article mainly focuses on the American poet and intellectual thinker, Henry Wadsworth Longfellow's social ecological wisdom by exploring everyman being equal: anti-slavery, and the harmonious development between nature and human society: anti-anthropocentrism in his poems on slavery, although in his poetry he also shows his wisdom of other two realms.

\section{B. A Brief Introduction of H.W. Longfellow}

Life is real-Life is earnest-

And the grave is not its goal;

...

Not enjoyment, and not sorrow,

Is our destined end or way;

But to act, that each to-morrow

Find us farther than to-day.

...

In the world's broad field of battle,

In the bivouac of Life,

Be not like dumb, driven cattle!

$\mathrm{Be}$ a hero in the strife!

Lives of great men all remind us

We can make our lives sublime,

And, departing, leave behind us

Footprints on the sands of time;

Let us, then, be up and doing,

With a heart for any fate;

Still achieving, still pursuing,

Learn to labor and to wait.

\footnotetext{
${ }^{[4]}$ Wenliang Liu.(2008). Ecocriticism from the Perspective of Cultural Poetics. Social Sciences in Yunnan,4,145-148.
} 
The excerpt above, taken from Henry Wadsworth Longfellow's poem A Psalm of Life, is probably best embodied by what Longfellow fulfilled in his life.

Henry Wadsworth Longfellow (1807-1882), a famous American poet, was born to a lawyer family in Portland, Maine, United States. Quite rich as he was, he strived to study hard and fulfill his dream to be admitted to Bowdoin College at the age of 15 , in the fall of 1822 . Pursuing his literary goals by submitting poetry and prose to various newspapers and magazines, between January 1824 and his graduation in 1825, he had published nearly 40 minor poems. When he graduated from Bowdoin, he was ranked fourth in the class, and had been elected to Phi Beta Kappa, and gave the student commencement address. Like other writers and poets such as Nathaniel Hawthorne, and Edgar Allen Poe in his time, life seemed to play jokes with him. He had experienced two tragedies in his life, which made life and death as important themes for his future poems characterized by his humanity and social ecological wisdom towards the suffering slaves. In 1834, his first wife, Mary Storer Potter died of a miscarriage in Rotterdam, when he journeyed in Europe as a preparation before he took the chair of the Smith Professorship of Modern Languages in Harvard College. "He was deeply saddened by her death, writing 'One thought occupies me night and day... She is dead-She is dead! All day I am weary and sad' [5]". Three years later, he was inspired to write the poem Footsteps of Angels about her. The other tragedy is the death of his second wife, Frances Appleton, the daughter of a wealthy Boston industrialist. Perhaps his seven-year Long courtship of Frances Appleton foreshadowed their unhappy ending. In 1861, their happy life came to an end. Longfellow's wife died of burns she received when the envelope of her children's locks and curls, which she was sealing with matches and wax, burst into flame and spread to her dress. Devastated by her death, he expressed his grief in the sonnet The Cross of Snow (1879), which he wrote eighteen years later to commemorate her death:

Such is the cross I wear upon my breast

These eighteen years, through all the changing scenes

And seasons, changeless since the day she died. ${ }^{[6]}$

Longfellow faced the two bitterest tragedies of his life. However, he never succumbed to life and fate. He, the hero still continued striving in life. He undertook the task of translating Dante into English and wrote many lyrics, ballads, and epic poems, such as Voices of the Night; The Courtship of Miles Standish; Evangeline: A Tale of Acadie, The Song of Hiawatha etc. He was regarded as the first American to translate Dante Alighieri's The Divine Comedy. In his old age, he had received numerous honors. He was given honorary degrees at the great universities of Oxford and Cambridge, invited to Windsor by Queen Victoria, and called by request upon the Prince of Wales. He was also "the first American poet to achieve an international reputation [7]64,", "the most popular living author in any genre in nineteenth-century

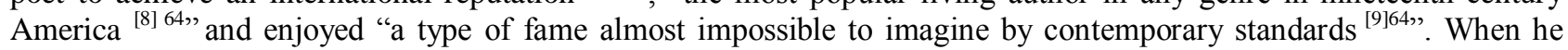
died in 1882, the first American bust of him was put in the Poet Corner of Westminster Abbey.

\section{LONGFELLOW's SOCIAL ECOLOGICAL WISDOM}

\section{A. Everyman Being Equal: Anti-Slavery}

Usually, the concept of everything being equal has been considered as a focus on the relationship between man and nature, while it is also focused on the relationship between human beings, that is, everyman being equal. As is known, human beings and any other creatures are all created equally and human beings have not any privilege or priority and are not superior to the latter. Therefore, human beings should treat everything not out of their own needs and benefits and meanwhile should not put everything of nature including human beings themselves in the conspicuous classification and hierarchy. Thus, the idea of putting human beings in the social hierarchy is an inexactitude. However, in the United States, the unfairness of putting human beings in the social hierarchy rests on the slavery system.

The first slaves arrived in Virginia around 1619, and slavery existed in America for the next 250 years. Africans made up the largest number of migrants to the New World during the colonial era, especially during the eighteenth century. During the four centuries of the Atlantic slave trade, an estimated 11 million Africans were transported to North and South America. In the United States, slaves had no rights. A slave could be bought and sold just like a cow or horse. Slaves had no say in where they lived or who they worked for. They had no representation in government. Slaves could not own property and were not allowed to learn or be taught how to read and write. Beginning in the 1750s, there was widespread sentiment that slavery was a social evil and should eventually be abolished, but even the Emancipation Proclamation of $1863 \mathrm{did}$ not end slavery. Slavery continued in the states that were part of the Union forces. Slavery came to an end in 1865 when the 13th Amendment was ratified after the end of the Civil War. ${ }^{[10]}$

In his poems of slavery, Longfellow advocates the socially ecological balance within human beings themselves in sublimating the concept of everyman being equal, echoing the Chinese scholar Lu Shuyuan's (2000, pp.146-7) and Chen Maolin's (2009,p.1) idea of social ecology, as one of the three important levels to study ecology in the field of

\footnotetext{
${ }^{[5]}$ Anonymous. Henry Wadsworth Longfellow http://en.wikipedia.org/wiki/Henry_Wadsworth_Longfellow.(accessed 6/ 1/2011).

${ }^{[6]}$ Ibid.

${ }^{[7]}$ Gioia, Dana. (2000). Longfellow in the Aftermath of Modernism. In Parini, Jay \& Miller, Brett C (eds). The Columbia History of American Poetry. Beijing: Foreign Language Teaching and Research Press.

${ }^{[8]}$ Ibid

${ }^{[9]}$ Ibid

[10] Anonymous. Slavery in America. http://www.uen.org/themepark/liberty/slavery.shtml (accessed 6/1/2011).
} 
eco-criticism, paying attention to the problems and conflicts within human beings. When human history enters a modern time, apart from the conflicts existing between human and nature, it also provokes equally serious problems between human beings themselves. It is the case of the slavery system in the USA in the Longfellow's time, even today still smoldering. The slavery system in essence is the hierarchical domination of the African Americans by the whites out of racial discrimination, and the deprivation of the Negro's human rights. To safeguard human freedom, Longfellow severely attacked the slavery system and his attitudes towards anti-slavery is mainly embodied in his 8 poems on slavery: To William E. Channing, The Slaves Dream, The Good Part that Shall not Be Taken Away, The Slavery in the Dismal Swamp, The Slave Singing at Midnight, The Witness, The Quadroon Girl and The Warning.

To William E. Channing is a poem Longfellow wrote in 1842 in testimony of his admiration for a great and good man when he heard of the death of Dr. Channing who was an abolitionist of slavery. As for The Slave's Dream, he eulogized the hardship, industriousness, and fortitudes of the slaves, and showed his sympathy for their hard and miserable life. He depicted a slavery dreamed a dream where he dreamed his journey back to his hometown in Africa and could have his freedom there, and "He did not feel the driver's whip,/ Nor the burning heat of day". How ironical it is!

In The Slavery in the Dismal Swamp, the poet compared the living situation of slaves to the dismal swamp:

Where will-o'-the-wisp and glow-worms shine,

In bulrush and in brake;

Where waving mosses shroud the pine,

And the cedar grows, and the poisonous vine

Is spotted like the snake;

Where hardly a human foot could pass,

Or a human heart would dare,

On the quaking turf of the green morass

He crouched in the rank and tangled grass,'

Like a wild beast in his lair.

The swamp is so dangerous and vile, even the human beings cannot pass. But who built this swamp? That is human beings themselves, more exactly the whites who think they are superior to the blacks. Who can save the slaves in this treacherous situation? Just as Longfellow, frustrated and sanguine, cried out in his poem The Slaves Singing at Midnight:

Paul and Silas, in their prison,

Sang of Christ, the Lord arisen,

And an earthquake's arm of might

Broke their dungeon-gates at night.

But, alas! What holy angel

Brings the Slave this glad evangel?

And what earthquake's arm of might

Breaks his dungeon-gates at night?

Paul and Silas in their prison can be saved by god when they pray, but can the slaves be equally saved when they pray too? In The Warning, Longfellow gave the whites a warning:

Beware! The Israelite of old, who tore

The lion in his path,- - when, poor and blind,

He saw the blessed light of heaven no more,

Shorn of his noble strength and forced to grind

In prison, and at last led forth to be

A pander to Philistine revelry,-

Upon the pillars of the temple laid

His desperate hands, and in its overthrow

Destroyed himself, and with him those who made

A cruel mockery of his sightless woe;

The poor, blind Slave, the scoff and jest of all,

Expired, and thousands perished in the fall!

There is a poor, blind Samson in this land,

Shorn of his strength and bound in bonds of steel,

Who may, in some grim revel, raise his hand,

And shake the pillars of this Commonweal,

Till the vast Temple of our liberties.

A shapeless mass of wreck and rubbish lies.

He satirically and ironically attacked the slavery system and hoped it could be abolished, and admonished that the whites and the blacks should live equally, peacefully and harmoniously, or the whites in the end would destroy themselves in its overthrow by laying their hands upon the pillars of the temple, or if the whites failed to change the situation, the slaves would "raise their hand and shake the pillars of this Commonweal". 


\section{B. The Harmonious Development between Nature and Human Society: Anti-anthropocentrism}

As human beings suffer more ecological crisis nowadays than before, one may raise the questions, "What is the root cause?" Is that because human beings use lots of chemical pesticides? Is that because we use biological and chemical weapons during wars? Those are not the root causes. The root cause lies in human beings' sense of superiority, more exactly anthropocentrism, which is fostered by human society. They believe, human beings are more granted rights by god and more superior to any other creatures, the belief of which can be traced back to the western biblical legend of how God created human beings. In the bible, God creates the world by creating the day and night first, then plants and animals, and last human beings. Most importantly and differently, it is well and widely believed God bestows on human beings great priorities and privileges to use and control any other creatures. The belief that the existence of any other creatures rests on serving human beings has since been imprinted and carved in human's minds. ${ }^{[11] 9}$ Therefore, human beings proudly consider themselves as "the center" of the world. Lynn White, an eco-critic, has pointed out that Christianity not only establishes the dualism, separating human beings and nature, but also insists that the exploitation of nature is the will of God. ${ }^{[12] 10}$ Driven by God's will, western countries have since put nature under control and exploitation out of the benefits and needs of human beings, just as William Rueckert has noted that the tragic flaw of human beings rests on the outlook of anthropocentrism, which guides human beings to conquer, tame, invade and exploit every entity of nature. ${ }^{[13] 113}$

When the history of human civilization wheels into the period of the Renaissance initiated in Europe, which advocates humanism, people enthusiastically cries out "Conquer Nature, Command nature, Control nature". The Three-C belief promotes and justifies human beings to continue exploiting nature with a sense of superiority. As human history moves into modern civilization, with the development of science and technology, people have ushered their unprecedented victory over nature. Victory? No. That is not a victory, for nature, black and blue, has revenged more bitterly on human beings.

It cannot be denounced and doubted that anthropocentrism has played its significant and remarkable role in the progress of human civilization, and yet it also brings human beings lots of detriments, and puts us under an ecological crisis. Nowadays, as the increasing threats to the existence of human beings that ecological crisis brings, the outlook of anthropocentrism has been challenged and criticized, and it also forces people to reconsider the relationship between human beings and nature. Lots of eco-critics (Glotfelty, 1996; Coup, 2000; Wang Nuo, 2003; and Chen Maolin,2009) advocate and consider anti-anthropocentrism as one solution to alleviate or phase out the ecological crisis. Only by abandoning the doctrines of anthropocentrism can human beings survive the crisis and live peacefully and harmoniously on earth. As a new outlook of eco-criticism, anti-anthropocentrism, the denouncement of anthropocentrism justifies the role of nature and regards human beings like any other creatures in nature as parts of the ecosystem on earth. Humans and nature are interrelated and interactive. That means how human beings treat nature is just the way they will be treated by nature.

The perception of anti-anthropocentrism, another ecological wisdom of Longfellow is conspicuously shown in his poems where nature is awesome, august and incontrollable to him. For instance, in Woods in Winter, he depicts a doleful and awesome picture of the winter. The original lines run like this:

When winter winds are piercing chill,

And through the hawthorn blows the gale,

With solemn feet I tread the hill,

That overbrows the lonely vale.

The poet seemingly treads the hill solemnly, but in a hidden sense, he is nothing but a week entity in the eyes of nature. Human beings cannot control the piercing chill, cannot change the fate of the lonely vale, even he treads the hill solemnly. Then, he continues:

Where, from their frozen urns, mute springs,

Pour out the river's gradual tide,

Shrilly the skater's iron rings,

And voices fill the woodland side.

In this treacherous changing season, the mute springs come out from the vale like a frozen urn, and pour out the river's gradual tide. Human beings are helpless in front of it but like a skater skates on the ice echoing the scene of winter. Here, it seems Longfellow points out a path for human beings to eliminate the ecological crisis that human beings should adapt themselves flexibly to nature and become friends with nature, just as he concludes at the end of the poem:

Chill airs and wintry winds! My ear

Has grown familiar with your song;

I hear it in the opening year,

I listen, and it cheers me long.

\footnotetext{
${ }^{[11]}$ Glotfelty, Cheryll \& Haroltd Fromm (eds.). (1996).The Ecocriticism Reader: Landmarks in Literary Ecology. Athens \& London: The University of Georgia Press.

${ }^{[12]}$ Ibid.

${ }^{[13]}$ Ibid.
} 
If human beings cast off the skin of anthropocentrism in front of nature, nature will become friends and live harmoniously with them. It will fulfill the balance between nature and human society.

\section{The ORIGIN OF LONGFELlOW's Social ECOLOGICAL IDEAS: THE INERASABLE INFLUENCE OF AMERICAN SOCIAL UPHEAVAL IN THE MidDLE 19TH CENTURY}

Like any other creatures, human beings are also living in and getting influenced by the "environmental niche". The term "niche", coined by Charles Elton in the late 1920s, refers to "the place a species occupies in the biotic community" ${ }^{[14] 31}$ or the environmental structure and condition which can maintain the life of a species. ${ }^{[15] 204}$ and "tells us that every entity, whether human or nonhuman, plays its unique role in keeping the integrity, stability and beauty of an ecosphere, and therefore every entity possesses intrinsic worth. ${ }^{[16] 31}$ " More often than not eco-critics utilize the theory of "niche" to investigate the development of a litterateur or an artist. The niche to human beings is much more complicated than to any other creatures governed by temperature, moisture, food, light, space, time etc. As a litterateur, he or she should not only be affected by his material and political conditions, but also be influenced by his or her culture, custom, value, and spiritual surroundings. And the latter would affect him or her more than the former. The present part is going to probe into the origin of Longfellow's ecological ideas by sub-exploring the living environment of Longfellow: the inerasable influence of American social upheaval in the middle of 19th century.

Longfellow lived most of his life in the $19^{\text {th }}$ century, where the USA underwent a tough time from an agricultural country to the industrial one. This special time led to the easy burst of every contradictory and triggering force. In the middle of the $19^{\text {th }}$ century, exactly from 1861 to 1865 , the USA saw the civil war between the North and the South on the issue of slavery. After the war, America developed at skyrocketing speed and saw the economic boom as well as faced fierce competition. In order to struggle to live, people tried everything they could. Behind the boom were large numbers of bloods, poverty, and misery. Capitalism brought about the financial crisis, the social upheavals, and the increasing unemployment. At the same time, the accomplishment of west movement had enlarged the gap between dream and reality. Nearly the whole society was under the dark cloud of frustration, disillusion, dissatisfaction, and resistance. The social ecosystem of the USA was in disconcerting unbalance, which inevitably would affect the spiritual ecology. That is why Longfellow turned to his poems to mediate on and confess the wrong doings of human beings, destructing the anthropocentrism and show his attitude of anti-slavery. "Longfellow, from the beginning of his career, was vigorous in his condemnation not just of slavery but of racial inequality in general." (Irmscher,2009,p.109) Just as during the 1860s, Longfellow supported abolitionism and especially hoped for reconciliation between the northern and southern states after the American Civil War, he wrote in his journal in 1878: "I have only one desire; and that is for harmony and a frank and honest understanding between North and South" ${ }^{[17]}$. Meanwhile he called on people in response to the call of nature in his poem Sunrise on the Hills:

If thou art worn and hard beset

With sorrows, that thou wouldst forget,

If thou wouldst read a lesson, that will keep

Thy heart from fainting and thy soul from sleep

Go to the woods and hills! No tears

Dim the sweet look that Nature wears.

According to Longfellow, if human beings feel weary, dreary, and sorrowful, and tired of the life in society, the woods which represent nature will embrace our heart from fainting, and our soul from sleep. Thus, we will get the sweetness from nature.

\section{CONCLUSION}

Out of the worsening global ecological crisis, and under the influence of the upsurge of environmental preservation movements as well as indifferences among the human beings, such as the still smoldering discrimination towards the blacks in the USA or the contempt on poor people from the riches all over the world, studying the poems on slavery of Henry Wadsworth Longfellow in the eco-critical aspect is highly and significantly relevant. Meanwhile, eco-criticism, as a cultural literary critical school sprouting early in the 1970s, and making its presence felt in literary circles in the 1990s, which is focused on ecological balances with the awakening of ecological consciousness as its central task, and on the study of the relationship between literature, culture, and environment, has also availed us of another way to study him.

Despite the fact that Henry Wadsworth Longfellow in a strict sense didn't really compose what eco-critics call "Ecological Writing", nor was he like the environmentalists calling on people to protect nature and the ecosystem directly, yet it will not be an impediment for us to read him in the perspective of eco-criticism.

\footnotetext{
${ }^{[14]}$ Maolin Chen.(2009). Poetic Dwelling: An Ecocritical Study of Henry David Thoreau. Zhejiang: Zhejiang University Press.

${ }^{[15]}$ Shuyuan Lu.(2000).Ecological Literature and Art Studies. Xi'an: Shaanxi People's Education Press.

${ }^{[16]}$ Maolin Chen. (2009). Poetic Dwelling: An Ecocritical Study of Henry David Thoreau. Zhejiang: Zhejiang University Press.

[17] Anonymous. Henry Wadsworth Longfellow. http://en.wikipedia.org/wiki/Henry_Wadsworth_Longfellow\#Later_life_and_death (accessed 6/1/2011).
} 
Setting Longfellow in the framework of eco-criticism, this paper has explored his ecological wisdom in his poems on slavery. As a common dweller on earth, he presents myriads of social ecological and ethic illumination and thoughts in pursuit of the ecological balance between nature and society, and even within human beings themselves. Under his ecological wisdom on human society, he concentrated on everyman being equal and his attitude on anti-slavery. He, like his contemporaries Henry David Thoreau, Edgar Allen Poe, criticized the slavery system, and anthropocentrism. The doctrine of anti-slavery and anthropocentrism is not acceptable and agreeable. In addition, the paper also probes into the origin of Longfellow's social ecological ideas in the angles of the living environment of Longfellow: the inerasable influence of American social upheaval in the Middle 19th Century.

Under the circumstance of the deterioration of ecosystem, the attempt to study Longfellow's social ecological wisdom is highly relevant. His social ecological wisdom, which comes to remind human beings of respecting, protecting and caring for other persons as well as nature, will provide a blueprint for human beings to develop a harmonious society, and "live a poetic life ${ }^{[18] \text { " }}$ by reconsidering the relationships within human beings, between nature and human beings, between nature and society, and between nature and human spirit. Only in the pursuit of harmonious co-existence in society and the peaceful and symbiotic development of nature and culture, and the balance between nature and human spirit, can the ecosystem operate in the virtuous circle and can human beings live a congenial life and poetically dwell on earth.

\section{REFERENCES}

[1] Coupe, Laurence (ed.). (2000). The Green Studies Reader: from Romanticism to Ecocriticism. New York: Routledge.

[2] Glotfelty, Cheryll \& Haroltd Fromm (eds.). (1996). The Ecocriticism Reader: Landmarks in Literary Ecology. Athens \& London: The University of Georgia Press.

[3] Irmscher, Christoph. (2009). Public Poet, Private Man: Henry Wadsworth Longfellow. Boston: University of Massachusetts Press.

[4] Maolin Chen. (2009). Poetic Dwelling: An Ecocritical Study of Henry David Thoreau. Zhejiang: Zhejiang University Press.

[5] Shuyuan Lu. (2000). Ecological Research in Literature and Art. Xi'an: Shaanxi People's Education Press.

[6] Nuo Wang. (2003). European and American Ecological Literature. Beijing: Peking University Press.

*All the poems quoted in this article are from The Complete Poetic Works of Henry Wadsworth Longfellow by Longfellow, Henry Wadsworth. (1899). Boston and New York: Houghton Mifflin.

Jingcheng Xu, was born in Fujian, China in 1986. He received his B.A. Degree as an English Major from Beijing Forestry University, China in 2010. He is currently a graduate student in the School of Foreign Languages, Being Forestry University, China. His research interests include British and American Literature, linguistics, teaching and education, and Chinese-English Translation.

Meifang Nan Gong was born in Shaanxi, China in 1972. She received her PhD Degree in Literature from Beijing Normal University, China in January, 2011. She is currently an associate professor in the School of Foreign Languages, Being Forestry University. Her research interests include British and American Literature and Western Literary Criticism.

\footnotetext{
[18] "Living a poetical life" one of the ideas and goals of eco-criticism, originally appeared in the poem of the German poet named Friedrich Holderlin (1770-1843). The original lines go like this: "Full of merits, yet poetically, man/Dwells on this earth." Later, the expression "poetically man dwells" has become well-known through the interpretation and evaluation of Martin Heidegger (1889-1976), a famous German philosopher in the field of existentialism. It has three aspects of its connotation: preservation, freedom, and harmony. That means that "all the natural entities on earth including human beings exist together freely, peacefully, and harmoniously.” (Quoted from Chen Maolin 2009, p.2)
} 